University of Arkansas, Fayetteville

ScholarWorks@UARK

$1-17-2017$

\title{
Private Schooling Promotes Political and Economic Freedom? An International Fixed Effects Instrumental Variables Analysis
}

Corey A. DeAngelis

University of Arkansas, Fayetteville, cadeange@uark.edu

M. Danish Shakeel

University of Arkansas, Fayetteville

Follow this and additional works at: https://scholarworks.uark.edu/edrepub

Part of the Educational Assessment, Evaluation, and Research Commons, Educational Leadership Commons, and the Other Educational Administration and Supervision Commons

\section{Citation}

DeAngelis, C. A., \& Shakeel, M. D. (2017). Private Schooling Promotes Political and Economic Freedom? An International Fixed Effects Instrumental Variables Analysis. Education Reform Faculty and Graduate Students Publications. Retrieved from https://scholarworks.uark.edu/edrepub/17

This Article is brought to you for free and open access by the Education Reform at ScholarWorks@UARK. It has been accepted for inclusion in Education Reform Faculty and Graduate Students Publications by an authorized administrator of ScholarWorks@UARK. For more information, please contact scholar@uark.edu. 


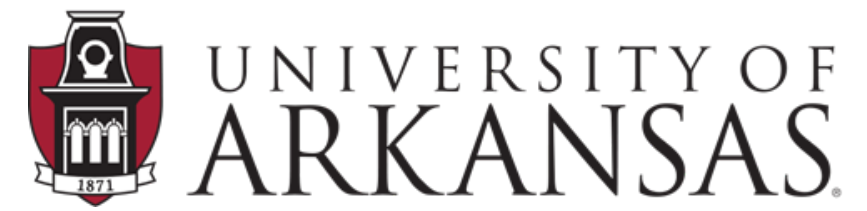

College of Education \& Health Professions Education Reform

\title{
WORKING PAPER SERIES
}

\section{Private Schooling Promotes Political and Economic Freedom? An International Fixed Effects Instrumental Variables Analysis}

\author{
Corey A. DeAngelis
}

M. Danish Shakeel

January 17, 2017

EDRE Working Paper 2017-03

The University of Arkansas, Department of Education Reform (EDRE) working paper series is intended to widely disseminate and make easily accessible the results of EDRE faculty and students' latest findings. The Working Papers in this series have not undergone peer review or been edited by the University of Arkansas. The working papers are widely available, to encourage discussion and input from the research community before publication in a formal, peer reviewed journal. Unless otherwise indicated, working papers can be cited without permission of the author so long as the source is clearly referred to as an EDRE working paper. 


\title{
Private Schooling Promotes Political and Economic Freedom? An International Fixed Effects Instrumental Variables Analysis
}

\author{
Corey A. DeAngelis \\ Department of Education Reform, \\ University of Arkansas \\ cadeange@uark.edu \\ M. Danish Shakeel \\ Department of Education Reform, \\ University of Arkansas \\ mdshakee@uark.edu
}

January 17, 2017

\section{Acknowledgements}

The content of the report is solely the responsibility of the authors and does not necessarily represent the views of the University of Arkansas. Corresponding author is Corey A. DeAngelis, cadeange@email.uark.edu. 


\begin{abstract}
Additional private schooling within a nation-state may increase citizens' political and economic freedom through increased educational quality, balanced power relationships, and increased civic engagement.

We employ a two-stage-least-squares time and country-level fixed-effects analytical technique to examine how private schooling could affect political rights, civil liberties and economic freedom indices. We also use a new instrumental variable, short-run fluctuations in the demand for schooling, to predict private schooling. We examine 174 different nations across the globe from 1999 to 2014, and find significant evidence to suggest that private schooling leads to enhanced political and economic freedom. In particular, our preferred model finds that a ten percentage point increase in private share of schooling enrollment within a nation, over time, is associated with a $7.4 \%$ of a standard deviation increase in the Political Rights Index and an $8 \%$ of a standard deviation increase in the Economic Freedom of the World Index.
\end{abstract}

Keywords: Private school; school choice; civic education; instrumental variables 


\section{Introduction}

The vast majority of private school choice evaluations focus on how private schooling can impact student standardized test scores. These evaluations find small positive benefits for student achievement overall (Shakeel, Anderson, \& Wolf, 2016) and larger positive impacts for student attainment (Neal, 1997; Warren, 2008; Cowen et al., 2013; Wolf et al., 2013). While the evidence on student test scores is saturated, the evidence for non-academic outcomes is less abundant.

Specifically, scarce evidence exists on the impact of private school choice programs on social goals such as tolerance of others, civic engagement, and criminal activity. Out of thirteen reviewed studies, we found no evidence to indicate that private school choice negatively impacts society. Overall, impacts are null to positive for tolerance, null to positive for civic engagement, and positive for social order. In particular, researchers found that the Milwaukee Parental Choice Program had mostly positive impacts on students' tolerance of others, political participation, volunteer activity, and criminal activity reduction (Fleming, 2014; Fleming, Mitchell, \& McNally, 2014; DeAngelis \& Wolf, 2016a; DeAngelis \& Wolf, 2016b).

Additionally, Wolf, Peterson, and West (2001) found that the DC Opportunity Scholarship Program had positive impacts on students' tolerance of others. Moreover, Bettinger and Slonim (2006) used a lab experiment to find that winning a private school choice voucher in Ohio increased the students' charitable giving.

Neal McCluskey (2013) examined the relationship between a centralization of schooling and generalized trust across 56 different countries, as measured by the World Values Survey, but did not find significant effects. In fact, he found that countries with greater centralized control of schooling tended to experience greater levels of trust, although the relationship was not 
statistically significant. This insignificance could be due to the lack of power generated by the small sample size, but even a detected significant relationship would not be considered causal due to the observational study design. Additionally, Shafiq and Myers (2014) found that access to private school vouchers in Sweden was associated with a slight increase in the students' civic attitudes between 1999 and 2009.

While the limited evidence indicates that school choice programs have a positive impact on broad social objectives in the United States, no studies have examined a causal relationship between private schooling and social goals at the international level. We add to the literature by examining the causal relationship between private schooling and indices of political and economic freedom by employing time and country-fixed effects regression integrated with twostage least squares regression.

\section{Theory}

Although there are many alternative strong theories for why increased private schooling could lead to more political and economic liberty, we outline the strongest three below.

First, an increase in private schooling can increase the quality of education for all citizens in a given country (Muralidharan \& Sundararaman, 2015; Shakeel, Anderson, \& Wolf, 2016; Tooley \& Dixon, 2005). An increase in private schooling can increase competitive pressures within the education system and therefore increase the quality of all schools (Egalite, 2013; Filglio \& Hart, 2014). Low-quality schools that do not increase quality by responding to the additional competitive pressures will be forced to face a shutdown condition if they do not provide an adequate experience for families (Friedman \& Friedman, 1990). Additionally, the 
quality of the educational experience may be enhanced simply due to the fact that there is an improved match of interests between educators and students.

Secondly, specialized learning environments can also lead to differentiated learning at the student level (Beck, Egalite, \& Maranto, 2014). A specialized, high-quality educational environment can increase the diversity of thought experienced by citizens within a country. Access to private schooling can also reduce the likelihood of a country-level governmental monopoly on the flow of information received through a system of public schooling. The diversity of thought created through specialized learning environments can increase the likelihood that students will engage in civic activity such as voting, contacting political representatives, supporting campaigns of their choice, and even peaceful protests (Fleming, 2014; Fleming, Mitchell, \& McNally, 2014).

If the citizenry is more educated about political engagements, and they take action based on their self-interests, decision-makers will face additional accountability (Przeworski \& Stokes, 1999). Since citizens are inherently interested in their rights and liberties, and they will be more likely to take actions to protect those rights and liberties, decision-makers will be more likely to pass policies that protect citizens' rights and liberties (Locke, 2016). Furthermore, if citizens are more engaged in political action, decision-makers will have an additional incentive to uphold transparency and decrease or eliminate engagement in corrupt activity. If politicians do not respond to these incentives in the short-run, they may lose their jobs through the accountability created by citizens' political participation.

A third hypothesis relates to the autonomy created for the families through private school choice. If a family can decide where their children go to school, they will feel an enhanced sense of autonomy and control. This increased sense of autonomy and control experienced by the 
parents and children may reduce their stress levels and therefore decrease the likelihood that they will engage in rebellious behavior. If citizens are behaving properly, or at least less-rebelliously, decision-makers will have less of an incentive to pass policies which restrict individual liberties. While this specific theory has not been empirically tested, there is significant evidence that autonomy leads to increased satisfaction and decreased stress (Finn, 2001). Greater levels of happiness and lower levels of stress lead to less irrational behaviors such as criminal activity and disrespect of others (Artello \& Williams, 2014).

Perhaps most importantly, access to private schooling can disperse the concentration of power held over the entire education system. In a fully-public system of schooling, public schools have a monopoly on the use of public funds. The monopoly on the use of public funds guarantees that there will be a large amount of monopoly power exercised by those running public schooling options. As a result, a relatively small number of centralized officials exercise power over a large number of constituents. The system of fully-public schooling, which allows a small number of individuals to hold a monopoly on power, can be more apt to promote deference to elites holding exorbitant authority. Furthermore, an education system which does not allow parents and children to hold enough actual power can cause the system to remain stagnant. A system of highly-skewed power could cause those without influence to learn that the only way to get something out of the system is to make the decision-makers happy through not challenging them (Gaventa, 1982). Generations of this type of schooling system could convince citizens that their actions in the political realm do not lead to desired outcomes. This indifference in the political sector could lead to policies which do not promote the best interest of the citizenry. Alternatively, a system of diverse schooling options could balance power relationships and teach 
citizens that their actions in the political realm could lead to improved outcomes (Stewart \&

Wolf, 2014).

\section{Data}

We use country-level data from multiple sources for the years 1999 to 2014 . We use data from the World Bank ${ }^{1}$ and the United Nations Data Retrieval System ${ }^{2}$ for our independent variable of interest, the private share of total schooling enrollment. We also use data from the World Bank for gross domestic product, population, life expectancy, total schooling enrollment and child share of population. We use the New World Encyclopedia ${ }^{3}$ to calculate the age of each sovereign state.

We use three data sources for our four dependent variables of interest. For our first two dependent variables measuring political freedom, the Political Rights Index and the Civil Liberties Index, we use publicly-available online data from Freedom House ${ }^{4}$ for the years 1999 to 2014. For our two dependent variables capturing economic freedom, we use publiclyavailable online data from Fraser Institute ${ }^{5}$ and The Heritage Foundation ${ }^{6}$ over the same time period. $^{7}$ Over this sixteen year period, we have access to sufficient data to analyze 174 countries with 1997 observations for the political freedom and civil liberties indices. Moreover, we have access to sufficient data to analyze 147 counties with 1465 observations for the Economic Freedom of the World Index and 159 countries with 1771 observations for the Index of Economic Freedom.

\footnotetext{
${ }^{1}$ http://data.worldbank.org/indicator/SE.SEC.PRIV.ZS

${ }^{2}$ http://data.un.org/Data.aspx?d=UNESCO\&f=series\%3APRP_1

${ }^{3}$ http://www.newworldencyclopedia.org/entry/List_of_sovereign_states_by_formation_date

${ }^{4}$ https://freedomhouse.org/report-types/freedom-world

${ }^{5}$ http://www.freetheworld.com/

${ }^{6}$ http://www.heritage.org/index/explore

${ }^{7}$ The Fraser Institute index is missing the year 1999, so that specific analysis is from 2000 to 2014.
} 


\section{Indices}

\section{Political Rights and Civil Liberties}

The Political Rights Index and Civil Liberties Index are both created by Freedom House annually in the Freedom in the World report. The index is created by a team of internal and external advisers and analysts from academia, think-tanks, and human rights communities. In 2016, the team scored 195 countries and consisted of over 80 analysts and around 30 advisors. The scores are largely based on the Universal Declaration of Human Rights ${ }^{8}$ which was adopted by the United Nations General Assembly in 1948.

Professional analysts evaluate each country on several variables ${ }^{9}$ such as electoral process, political pluralism, political participation, functioning of government, freedom of expression, freedom of belief, associational rights, organizational rights, rule of law, personal autonomy, and individual rights. Some example questions include:

- Is the head of government or other chief authority elected through free and fair elections?

- Are there free trade unions and peasant organizations or equivalents, and is there effective collective bargaining?

- Are there free professional and other private organizations?

Nations that receive the highest political rights scores are those that have an abundance of political rights such as free and fair elections. The elected candidates are the ones that actually rule and political parties actively compete with one another. Additionally, the interests of minorities in society are represented in political realms. Nations that receive the highest civil liberties scores are those that allow for liberties such as freedom of expression, assembly,

\footnotetext{
${ }^{8}$ http://www.un.org/en/universal-declaration-human-rights/

${ }^{9}$ https://freedomhouse.org/report/freedom-world-2016/methodology
} 
association, education, and religion. These nations have equal opportunity before the law and free economic activity.

Freedom House reports these indices from one to seven, with one being the most desirable score. Since these are measures of rights and liberties, we transform the scores to make one the least desirable and seven the most desirable score. Mainwaring, Brinks, and Pérez-Liñán (2007) find that these indices have a correlation of over $80 \%$ with other democracy-based indices.

\section{Economic Freedom of the World}

The Economic Freedom of the World Index ${ }^{10}$ is produced by the Fraser Institute annually. This index was created as a response to dissatisfaction with the scope of the Freedom House indices. Beginning in 1986, Milton Friedman and Michael Walker began by holding conferences with about 60 economists on the meaning and measurement of economic freedom. The takeaway from these conferences was that economic freedom was characterized by personal choice, voluntary exchange, freedom to enter and compete in markets and protection of people and their property. These conferences also resulted in the creation of the Economic Freedom of the World Index (Gwartney, Lawson, and Block, 1996).

This index was first published in 1996 and contains 42 measures and 24 components within five different equally-weighted categories related to economic freedom: size of government, legal structure and security of property rights, access to sound money, freedom to trade internationally, and regulation of credit, labor, and business. Each component is scaled from 0 to 10, with 10 being the highest score for economic freedom. The average of the components within a category is the score for that given category. The average of the five main

\footnotetext{
${ }^{10}$ http://www.freetheworld.com/
} 
categories is the overall index score for a given country in a particular year. In the 2015 report $^{11}$ of 157 countries, Hong Kong scored the highest with an 8.97 and Venezuela scored the lowest with a 3.23. Venezuela switched to a full-blown dictatorship, without elections, only one year after the 2015 report (Toro, 2016).

\section{Index of Economic Freedom}

The Index of Economic Freedom, ${ }^{12}$ an annual report measuring economic freedom within nations over time, was created by The Heritage Foundation and The Wall Street Journal in 1995. The index takes on values from 0 to 100 and is composed of ten different factors that influence economic freedom: property rights, freedom from corruption, fiscal freedom, government size, business freedom, labor freedom, monetary freedom, trade freedom, investment freedom, and financial freedom. These ten variables take on values from 0 to 100 and are averaged in order to calculate a nation's overall index score for a given year. The ten variables are categorized into four different sections: rule of law, limited government, regulatory efficiency, and open markets. Additional details on the specific methodology and sources used to calculate each of the ten variable scores can be found at the Heritage website. ${ }^{13}$

Out of the 186 countries measured in 2016, Hong Kong scored the highest with an 88.6 and North Korea scored the lowest with a 1.3. Will Wilkinson (2007) found that higher economic freedom as measured by the Fraser Institute and Heritage Foundation indices is strongly correlated with self-reported happiness. Other scholars have found the same result: that economic freedom indices are more strongly correlated with happiness than any other variable used (Ott, 2005; Ovaska \& Takashima, 2006).

\footnotetext{
${ }^{11} \mathrm{http} / / /$ www.freetheworld.com/2015/economic-freedom-of-the-world-2015.pdf

${ }^{12} \mathrm{http}: / /$ www.heritage.org/index/about

${ }^{13}$ http://www.heritage.org/index/book/methodology
} 


\section{Methods}

We use a time and country fixed effects regression approach of the form:

$$
\begin{aligned}
\text { Freedom }_{\text {it }}= & \beta_{0}+\beta_{1} \text { PrivateShare }_{\text {it }}+\beta_{2} \text { GDP }_{\text {it }}+\beta_{3} \text { GovtExpend }_{i t}+\beta_{4} \text { Pop }_{i t}+\beta_{5} \text { Enroll }_{\text {it }}+ \\
& \beta_{6} \text { LifeExpect }_{\text {it }}+\beta_{7} \text { Mortality }_{\text {it }}+\beta_{8} \text { Age }_{\text {it }}+\beta_{9} \text { Urban }_{\text {it }}+\alpha_{i}+\varepsilon_{\text {it }}
\end{aligned}
$$

Where Freedom is one of the three dependent variables of interest for country $i$ at time period $t$. These include two indices provided by Freedom House, the Political Rights Index and the Civil Liberties Index, and two indices provided by Fraser Institute and The Heritage Foundation measuring economic freedom. The Political Rights Index and the Civil Liberties Index are on a scale from one to seven, the Index of Economic Freedom is on a scale from 0 to 100, and the Economic Freedom of the World Index is on a scale from 0 to 10 . We transform all indices so that higher values are considered more desirable.

PrivateShare is the independent variable of interest, the private school share of total enrollment, for country $i$ in time period $t$. We expect that the coefficient of interest, $\beta_{1}$, will be positive since private schooling can increase diversity of thought and decrease concentration of power which can lead to increased political and economic freedom.

We include a set of country-level control variables since certain characteristics of countries may cause them to become more free as well as increase private-sector schooling. For example, an increase in GDP could lead a country to increase spending on public schooling since it has more wealth. Concurrently, the Freedom Index for a country is likely to increase due to an increase in its wealth. GDP is the gross domestic product, in billions, for country $i$ in year $t$. GovtExpend is the government expenditure as a percent of GDP, Pop is the population in millions, Age is the number of years of existence for each nation-state, LifeExpect is the average 
life expectancy, Mortality is the infant mortality rate, Urban is the percent a population living in an urban area, and Enroll is the total number of students enrolled in private and public schooling for country $i$ in time period $t$. Due to the non-linear relationship between the dependent variables and GDP, population, and enrollment, we also include squares of these terms in our models. Finally, $\alpha_{i}$ is the set of country-level time-invariant parameters, such as ethnicity, language, and culture, and $\varepsilon_{\mathrm{it}}$ is the random error term.

Since a time and country fixed effects approach may still produce biased estimates if there are time-variant omitted variables, or if there is reverse-endogeneity, we also employ a time and country fixed effects two-stage least squares regression of the form:

$$
\begin{aligned}
& \text { PrivateShare }_{i t}=\lambda_{0}+\lambda_{1} \text { ChildPop }_{i t}+\lambda_{2} X_{i t}+\alpha_{i}+\varepsilon_{i t} \\
& \text { Freedom }_{i t}=\beta_{0}+\beta_{1} \text { PrivateShare }_{i t}+\beta_{2} X_{i t}+\alpha_{i}+\varepsilon_{i t}
\end{aligned}
$$

Where the second-stage endogenous explanatory variable of interest, PrivateShare, is predicted in the first stage with an exogenous instrument, ChildPop, the percent of the total population that is between the ages of 0 and 14 for country $i$ in year $t$. The instrument represents an unexpected shock in the demand for schooling overall in the short-run. Since almost all public school systems around the world are constitutionally-obligated to provide a free education for all children, public schools will be more likely to absorb this excess demand. On the other hand, private schools will be less likely to respond to short-run shocks in demand since the profitincentives for school expansion and market entry may not appear quickly enough.

Because of this, we expect that the instrument will be strongly negatively correlated to the share of private schooling enrollment within a country and year. The instrument passes the redundancy condition since it does not directly affect our outcome variables of interest; the amount of children in a given country/year should not directly affect political or economic 
freedom within a country/year. Furthermore, when we include this instrument in our structural model, we do not find evidence that the instrument is correlated with any of the outcome variables. Lastly, the instrument is exogenous since it is not correlated with any omitted variables that may concern us. For example, a government could pass a policy such as decreased tax rates. This decrease in tax rates could theoretically increase the presence of private schooling and simultaneously increase political and economic freedom indices, but the presence of children within a country/year is not related to tax rates. We also include all of the same controls from our previous models in vector $\mathrm{X}$.

Since many observable characteristics of countries can be argued as relatively constant over time, we first present results for the country-level fixed-effects models without time-variant controls. Finally, we present results based on our preferred models with country-level timevariant controls.

Table 1: Descriptive Statistics

\begin{tabular}{lccccc}
\hline & Mean & $\begin{array}{c}\text { Standard } \\
\text { Deviation }\end{array}$ & $\begin{array}{c}\text { Within } \\
\text { Std. Dev. }\end{array}$ & Minimum & Maximum \\
\hline Political Rights & 4.99 & 2.04 & 0.55 & 1 & 7 \\
Civil Liberties & 5.02 & 1.63 & 0.42 & 1 & 7 \\
Fraser - Economic & 6.94 & 0.86 & 0.30 & 4 & 9 \\
Heritage - Economic & 61.83 & 9.56 & 3.30 & 26.3 & 87.3 \\
\hline Private Share & 13.49 & 17.04 & 2.97 & 0.01 & 98.9 \\
GDP (Billions) & 405.07 & $1,465.58$ & 319.98 & 0.17 & $16,663.16$ \\
Govt Expend (\% GDP) & 16.25 & 5.74 & 3.21 & 2.8 & 54.8 \\
Population (Millions) & 31.84 & 101.27 & 6.95 & 0.05 & $1,357.38$ \\
Enrollment (Millions) & 3.07 & 8.40 & 1.19 & 0.01 & 108.93 \\
Urban & 57.67 & 22.52 & 2.20 & 8.46 & 100 \\
\hline
\end{tabular}




\begin{tabular}{lccccc}
\hline Life Expectancy & 70.07 & 9.08 & 1.85 & 40 & 83 \\
Infant Mortality & 27.05 & 26.45 & 7.35 & 2 & 141 \\
Country Age & 177.84 & 359.42 & 4.61 & 1 & 2,673 \\
\hline
\end{tabular}

\section{Country/Year Fixed Effects Results}

Table 2 reports results for a simple model which only controls for country fixed effects. Results in this first model indicate that an increase in private share of total schooling enrollment is associated with higher scores on all four indices.

In particular, Table 2 shows that a ten percentage point increase in the private share of schooling enrollment is associated with around a tenth of a unit increase in the political rights and civil liberties indices. Since these particular indices have a total of seven different units, these results are equivalent to around a 1.6\% increase in the political rights and civil liberties scores. The effect sizes are around $5.4 \%$ of a standard deviation for political rights and $6.7 \%$ of a standard deviation for civil liberties. These effect sizes are considered small using standards created by Jacob Cohen (1992) and Mark Lipsey (1990). However, for research in education, these effect sizes may be considered impressive (Hill et al., 2008). Additionally, a ten percentage point increase in the private share of schooling enrollment is associated with a 0.12 point increase in the Economic Freedom of the World Index and a 0.72-point increase in the Index of Economic Freedom. This is around a 14\% of a standard deviation increase for the Economic Freedom of the World Index and an $8 \%$ of a standard deviation increase for the Index of Economic Freedom.

Table 2: The Effect of Private Schooling on Political and Economic Freedom Indices

$\begin{array}{llll}\text { Political } & \text { Civil } & \text { Economic Freedom } & \text { Index of Economic }\end{array}$




\begin{tabular}{|c|c|c|c|c|}
\hline & Rights & Liberties & of the World & Freedom \\
\hline Private Share & $\begin{array}{l}0.011 * * \\
(0.007)\end{array}$ & $\begin{array}{c}0.011^{* * * *} \\
(0.000)\end{array}$ & $\begin{array}{l}0.012^{* * *} \\
(0.000)\end{array}$ & $\begin{array}{l}0.072 * * \\
(0.006)\end{array}$ \\
\hline Constant & $\begin{array}{c}4.726 * * * \\
(0.000)\end{array}$ & $\begin{array}{c}4.774 * * * \\
(0.000)\end{array}$ & $\begin{array}{c}6.696^{* * *} \\
(0.000)\end{array}$ & $\begin{array}{c}60.423 * * * \\
(0.000)\end{array}$ \\
\hline R-Squared Within & 0.0040 & 0.0074 & 0.0127 & 0.0047 \\
\hline Countries & 174 & 174 & 147 & 159 \\
\hline $\mathrm{N}$ & 1997 & 1997 & 1465 & 1771 \\
\hline
\end{tabular}

Note: P-values in parentheses. All models use country fixed effects.

$* \mathrm{p}<0.05,{ }^{* *} \mathrm{p}<0.01, * * * \mathrm{p}<0.001$

Since there are important factors that may significantly vary within countries in a relatively short time period, we include two more models which control for many of these factors. Table 3 reports results for our preferred model which includes time and country fixed effects. These results indicate that an increase in private share of schooling enrollment is associated with an increase in political rights and economic freedom.

Specifically, Table 3 shows that a ten percentage point increase in the private share of schooling enrollment is associated with a 0.15 -unit increase in the political rights index, or about $7.4 \%$ of a standard deviation. More notably, a ten percentage point increase in the private share of schooling enrollment is associated with a 0.07 -unit increase in the Economic Freedom of the World index, or about $8 \%$ of a standard deviation. These results are quite similar to those in the models without controls. This may be because the control variables are relatively stable over time within countries.

The control variables behave as expected where significance arises. Large increases in a country's GDP are associated with increases in civil liberties and economic freedom, though there are diminishing returns to GDP. It seems that more wealth within a country allows for more political and economic liberty, perhaps because additional resources increase living 
standards. Increases in government expenditures are associated with enhanced political rights and civil liberties. Governments can allocate resources towards programs which increase the perceived political freedom experienced by citizens. Alternatively, governments that respect the political freedom of its citizens may also allocate resources relatively efficiently and therefore receive less political pressure from its citizens regarding taxation policies.

An increase in population seems to be associated with lower levels of economic freedom, though there is evidence of diminishing losses. This could be because higher levels of population within a country magnify the economic problem of scarcity when access to resources remains relatively constant. There is some evidence to suggest that higher total schooling enrollment is associated with less civil liberties and economic freedom. It may be an increase in forced schooling, which is argued as necessary for social order, leads to less civil liberties. Additionally, while higher enrollment in schooling can lead to an educated workforce in the long-run, it may lead to decreased economic success in the short-run. The increase in number of people in the education sector decreases the number of people in the labor force in the short-run, which likely decreases production in the short-run.

Higher life expectancy within a nation is associated with less economic freedom, perhaps because a higher percentage of the population collecting retirement benefits, without additional production, increases economic pressures related to scarcity of resources (Olson, 2008). Higher rates of infant mortality are associated with lower economic freedom, perhaps because less economic freedom and resources decrease the likelihood that infants will receive adequate nutrition and care. Larger amounts of the population located in urban areas is associated with less political and economic freedom, perhaps because urban areas are more likely to experience various social problems such as crime and excessive competition for resources, however the 
relationship is not significant. Finally, older nation-states are mostly associated with more civil and economic liberties, as expected. It is likely that nation-states which respect political and economic liberties are those that remain intact; revolution is less likely to occur within countries with governments that do not attempt to control and deceive their citizens.

Table 3: The Effect of Private Schooling on Political and Economic Freedom Indices

\begin{tabular}{|c|c|c|c|c|}
\hline & $\begin{array}{c}\text { Political } \\
\text { Rights }\end{array}$ & $\begin{array}{c}\text { Civil } \\
\text { Liberties }\end{array}$ & $\begin{array}{l}\text { Economic Freedom } \\
\text { of the World }\end{array}$ & $\begin{array}{l}\text { Index of Economic } \\
\text { Freedom }\end{array}$ \\
\hline Private Share & $\begin{array}{c}0.015 * * \\
(0.004)\end{array}$ & $\begin{array}{l}-\mathbf{- 0 . 0 0 3} \\
(0.395)\end{array}$ & $\begin{array}{l}0.007 * \\
(0.041)\end{array}$ & $\begin{array}{c}0.013 \\
(0.686)\end{array}$ \\
\hline GDP (Billions) & $\begin{array}{l}-0.000 \\
(0.184)\end{array}$ & $\begin{array}{l}0.000 * \\
(0.012)\end{array}$ & $\begin{array}{c}0.000 \\
(0.145)\end{array}$ & $\begin{array}{c}0.001 \\
(0.065)\end{array}$ \\
\hline $\mathrm{GDP}^{2}$ (Billions) & $\begin{array}{c}-0.000 \\
(0.509)\end{array}$ & $\begin{array}{c}-0.000 * * * \\
(0.000)\end{array}$ & $\begin{array}{c}-0.000 * * * \\
(0.000)\end{array}$ & $\begin{array}{l}-0.000 \\
(0.249)\end{array}$ \\
\hline
\end{tabular}




\begin{tabular}{|c|c|c|c|c|}
\hline Population (Millions) & $\begin{array}{c}0.011 \\
(0.275)\end{array}$ & $\begin{array}{c}0.010 \\
(0.142)\end{array}$ & $\begin{array}{l}-0.010 \\
(0.069)\end{array}$ & $\begin{array}{c}-0.287 * * * \\
(0.000)\end{array}$ \\
\hline Population $^{2}$ (Millions) & $\begin{array}{c}0.000 * * \\
(0.003)\end{array}$ & $\begin{array}{c}0.000 \\
(0.922)\end{array}$ & $\begin{array}{c}0.000 * * * \\
(0.000)\end{array}$ & $\begin{array}{l}0.000^{*} \\
(0.012)\end{array}$ \\
\hline Enrollment (Millions) & $\begin{array}{l}-0.000 \\
(0.164)\end{array}$ & $\begin{array}{c}-0.000 * \\
(0.035)\end{array}$ & $\begin{array}{c}-0.000 \\
(0.094)\end{array}$ & $\begin{array}{l}-0.000 \\
(0.642)\end{array}$ \\
\hline Enrollment $^{2}$ (Millions) & $\begin{array}{c}0.000 * * \\
(0.003)\end{array}$ & $\begin{array}{c}0.000 \\
(0.363)\end{array}$ & $\begin{array}{c}0.000 * * * \\
(0.000)\end{array}$ & $\begin{array}{l}0.000 * \\
(0.014)\end{array}$ \\
\hline Govt Expend & $\begin{array}{l}0.012 * \\
(0.041)\end{array}$ & $\begin{array}{c}0.017 * * * \\
(0.000)\end{array}$ & $\begin{array}{c}-0.004 \\
(0.425)\end{array}$ & $\begin{array}{c}0.021 \\
(0.648)\end{array}$ \\
\hline Percent Urban & $\begin{array}{l}-0.015 \\
(0.142)\end{array}$ & $\begin{array}{l}-0.010 \\
(0.125)\end{array}$ & $\begin{array}{l}-0.010 \\
(0.102)\end{array}$ & $\begin{array}{l}-0.017 \\
(0.776)\end{array}$ \\
\hline Country Age & $\begin{array}{c}0.008 \\
(0.278)\end{array}$ & $\begin{array}{c}0.024 * * * \\
(0.000)\end{array}$ & $\begin{array}{l}-0.001 \\
(0.728)\end{array}$ & $\begin{array}{c}0.219 * * * \\
(0.000)\end{array}$ \\
\hline Infant Mortality & $\begin{array}{l}-0.002 \\
(0.725)\end{array}$ & $\begin{array}{c}-0.001 \\
(0.753)\end{array}$ & $\begin{array}{c}-0.022 * * * \\
(0.000)\end{array}$ & $\begin{array}{c}-0.071 * \\
(0.011)\end{array}$ \\
\hline Life Expectancy & $\begin{array}{c}0.010 \\
(0.563)\end{array}$ & $\begin{array}{c}0.010 \\
(0.411)\end{array}$ & $\begin{array}{c}0.003 \\
(0.766)\end{array}$ & $\begin{array}{c}-0.279 * * \\
(0.005)\end{array}$ \\
\hline Constant & $\begin{array}{c}2.392 \\
(0.100)\end{array}$ & $\begin{array}{c}0.611 \\
(0.534) \\
\end{array}$ & $\begin{array}{c}7.905 * * * \\
(0.000)\end{array}$ & $\begin{array}{c}52.979 * * * \\
(0.000)\end{array}$ \\
\hline R-Squared Within & 0.0384 & 0.2119 & 0.2089 & 0.0721 \\
\hline Countries & 154 & 154 & 135 & 146 \\
\hline $\mathrm{N}$ & 1698 & 1698 & 1328 & 1592 \\
\hline
\end{tabular}

Note: P-values in parentheses. All models include country and year fixed effects.

$* \mathrm{p}<0.05, * * \mathrm{p}<0.01, * * * \mathrm{p}<0.001$

\section{Two-Stage Least Squares Fixed Effects Results}

Table 4 reports the results based on the two-stage least squares country/year fixed effects regression below. The coefficients are all positive and larger in absolute value, however only two of the results are statistically significant with this analytic strategy. A ten percentage point increase in the predicted private share of schooling enrollment is associated with a 0.56 -point increase, or about a third of a standard deviation increase in the civil liberties index, and a 0.48 - 
point increase, or over a half of a standard deviation increase in the Economic Freedom of the

World Index. Again, the coefficients on the control variables behave as expected.

In each of the four models, the coefficient on the instrument is highly statistically significant in the first-stage with a p-value of about zero. A one percentage point increase in the child share of the population is associated with between a 0.43 and 0.71 percentage point reduction in the private share of schooling enrollment. As expected, exogenous increases in short-run demand for schooling are absorbed by the public school sector, likely because they are obligated to provide free schooling to all children, while private schools are not likely to respond to short-run financial incentives as quickly. Furthermore, the instrument is redundant since it is not significantly related to any of our outcome variables empirically or intuitively.

The increase in effect sizes that we observe can be explained in at least two ways. If the instrument is not exogenous, it may introduce more bias into our model than it removes.

However, the instrument appears to be intuitively and empirically less endogenous to the model than private schooling itself. In fact, it may be that the omitted variables bias within the original model actually has a significant negative impact on our outcome variables. The instrumental variable could attenuate the negative omitted variables bias and result in the revelation of the large and unbiased effect size.

Table 4: The Effect of Private Schooling on Political and Economic Freedom Indices

\begin{tabular}{lcccc}
\hline & $\begin{array}{c}\text { Political } \\
\text { Rights }\end{array}$ & $\begin{array}{c}\text { Civil } \\
\text { Liberties }\end{array}$ & $\begin{array}{c}\text { Economic Freedom } \\
\text { of the World }\end{array}$ & $\begin{array}{c}\text { Index of Economic } \\
\text { Freedom }\end{array}$ \\
\hline Predicted Private Share & $\begin{array}{c}\mathbf{0 . 0 1 8} \\
\mathbf{( 0 . 5 5 4 )}\end{array}$ & $\begin{array}{c}\mathbf{0 . 0 5 6 *} \\
\mathbf{( 0 . 0 1 3 )}\end{array}$ & $\begin{array}{c}\mathbf{0 . 0 4 8} * * * \\
\mathbf{( 0 . 0 0 0 )}\end{array}$ & $\begin{array}{c}\mathbf{0 . 1 2 0} \\
\mathbf{( 0 . 3 5 0 )}\end{array}$ \\
Controls & Yes & Yes & Yes & Yes \\
\hline R-Squared Within & 0.0382 & 0.0708 & 0.0960 & 0.0649 \\
\hline Countries & 152 & 152 & 135 & 146 \\
\hline
\end{tabular}




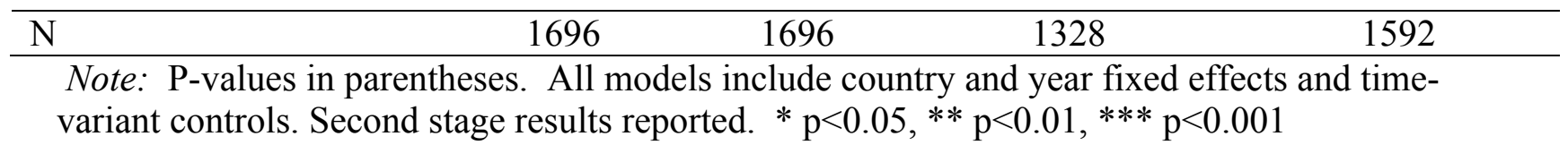

\section{Conclusion and Policy Implications}

School choice program evaluations have found that access to private schooling increases civic outcomes for students. In the United States, six studies have found null to positive effects on tolerance of others, four have found null to positive effects on civic engagement, and three have found positive effects on crime reduction. Although a few school choice program evaluations around the world have examined the effect of private schooling on civic outcomes of students, none have attempted to examine the causal impact of private schooling on political and economic freedom at the global level.

Our results largely indicate that the private share of schooling can increase political and economic freedom indices within a nation-state, but decision-makers must realize that private schooling will have different effects in different countries and other time periods. Furthermore, since this is the first study to examine these specific relationships, additional research is encouraged and necessary for stronger policy recommendations. In particular, we stress that the observed relationships are likely to be structural and, therefore, less likely to accrue benefits in the short-run. Nonetheless, our study provides robust evidence that private schooling can be beneficial to broad social goals such as political and economic freedom within a nation-state.

Based on the evidence, it would be wise for decision-makers to increase access to private schooling option through increased funding for private school choice programs. This would entice additional private schools to enter the market for schooling, which would reduce the overall price of schooling while increasing the number of options available to families. In order 
to increase the supply of private schooling options, policy-makers may also consider reducing regulatory costs for private schools to participate in school choice programs. Lastly, we should increase the amount of data available on private schooling around the world, so that researchers could provide more information about differential impacts for subgroups.

\section{References}

Artello \& Williams (2014). Stress and Crime. The Wiley Blackwell Encyclopedia of Health, Illness, Behavior, and Society.

Beck, D., Egalite, A., \& Maranto, R. (2014). Why They Choose and How It Goes: Comparing Special Education and General Education Cyber Student Perceptions. Computers \& Education, 76, 70-79. 
Bettinger, E., \& Slonim, R. (2006). Using Experimental Economics to Measure the Effects of a Natural Educational Experiment On Altruism. Journal of Public Economics, 90(8), 1625 1648.

Cohen, J. (1992). A power primer. Psychological Bulletin, 112(1), 155.

Cowen, J. M., Fleming, D. J., Witte, J. F., Wolf, P. J., \& Kisida, B. (2013). School Vouchers and Student Attainment: Evidence from a State-Mandated Study of Milwaukee's Parental Choice Program. Policy Studies Journal, 41(1), 147-168.

DeAngelis, C., \& Wolf, P. J. (2016a). The School Choice Voucher: A 'Get Out of Jail' Card? EDRE Working Paper 2016-03. Available at SSRN: https://ssrn.com/abstract=2743541

DeAngelis, C., \& Wolf, P. J. (2016a). Can Democracy Survive Private School Choice? The Effect of the Milwaukee Parental Choice Program on Voting Behavior. Unpublished manuscript, Department of Education Reform, University of Arkansas.

Egalite, A. J. (2013). Measuring Competitive Effects from School Voucher Programs: A Systematic Review. Journal of School Choice, 7(4), 443-464.

Finn, C. (2001). Autonomy: An Important Component for Nurses' Job Satisfaction. International Journal of Nursing Studies, 38(3), 349-357.

Fleming, D. J. (2014). Learning from schools: School Choice, Political Learning, and Policy Feedback. Policy Studies Journal, 42(1), 55-78.

Fleming, D. J., Mitchell, W., \& McNally, M. (2014). Can Markets Make Citizens? School Vouchers, Political Tolerance, and Civic Engagement. Journal of School Choice, 8(2), 213-236.

Figlio, D., \& Hart, C. (2014). Competitive Effects of Means-Tested School Vouchers. American Economic Journal: Applied Economics, 6(1), 133-156. 
Friedman, M., \& Friedman, R. (1990). Free to Choose: A Personal Statement. Houghton Mifflin Harcourt.

Gaventa, J. (1982). Power and Powerlessness: Quiescence and Rebellion in an Appalachian Valley. University of Illinois Press.

Gwartney, J., Lawson, R., \& Block, W. (1996). Economic Freedom of the World, 1975-1995, The Fraser Institute, Vancouver.

Hill, C. J., Bloom, H. S., Black, A. R., \& Lipsey, M. W. (2008). Empirical Benchmarks for Interpreting Effect Sizes in Research. Child Development Perspectives, 2(3), 172-177.

Lipsey, M. W. (1990). Design Sensitivity: Statistical Power for Experimental Research (Vol. 19). Sage.

Locke, John. Second Treatise of Government and A Letter Concerning Toleration. Oxford University Press, 2016.

Mainwaring, S., Brinks, D., \& Pérez-Liñán, A. (2007). Classifying Political Regimes in Latin America, 1945-2004. Regimes and democracy in Latin America: Theories and methods, $123-160$.

McCluskey, N. P. (2013). Education and Social Capital Maximization: Does Decentralization Hold the Key? (Doctoral dissertation, George Mason University).

Muralidharan, K., \& Sundararaman, V. (2015). The Aggregate Effect of School Choice: Evidence from a Two-Stage Experiment in India. The Quarterly Journal of Economics, 130(3), 1011-1066.

Neal, D. (1997). The Effects of Catholic Secondary Schooling On Educational Achievement. Journal of Labor Economics, 98-123. 
Olson, M. (2008). The Rise and Decline of Nations: Economic Growth, Stagflation, And Social Rigidities. Yale University Press.

Ott, J. (2005). Level and Inequality of Happiness in Nations: Does Greater Happiness of a Greater Number Imply Greater Inequality in Happiness? Journal of Happiness Studies, 6(4), 397-420.

Ovaska, T., \& Takashima, R. (2006). Economic Policy and The Level of Self-Perceived WellBeing: An International Comparison. The Journal of Socio-Economics, 35(2), 308-325.

Przeworski, A., \& Stokes, S. C. (1999). Democracy, Accountability, and Representation (Vol. 2). Cambridge University Press.

Shafiq, M. N., \& Myers, J. P. (2014). Educational Vouchers and Social Cohesion: A Statistical Analysis of Student Civic Attitudes in Sweden, 1999-2009. American Journal of Education, 121(1), 111-136.

Shakeel, M., Anderson, K. P., \& Wolf, P. J. (2016). The Participant Effects of Private School Vouchers Across the Globe: A Meta-Analytic and Systematic Review. EDRE Working Paper No. 2016-07. Available at SSRN: https://ssrn.com/abstract=2777633.

Stewart, T., \& Wolf, P. J. (2014). The School Choice Journey: School Vouchers and The Empowerment of Urban Families. Palgrave Macmillan.

Tooley, J., \& Dixon, P. (2005). Private Education Is Good for The Poor: A Study of Private Schools Serving the Poor in Low-Income Countries. Washington, DC: Cato Institute. Toro, F. (2016, October 21). It's Official: Venezuela is a Full-Blown Dictatorship. Retrieved October 23, 2016, from https://www.washingtonpost.com/news/globalopinions/wp/2016/10/21/its-official-venezuela-is-adictatorship/?utm_term=.fdfd73eb150d 
Wilkinson, W. (2007). In Pursuit of Happiness Research: Is It Reliable? What Does It Imply for Policy? The Cato Institute, Policy Analysis No. 590.

Wolf, P. J., Peterson, P. E., \& West, M. R. (2001). Results of a School Voucher Experiment: The Case of Washington, DC after Two Years. 